\title{
Biofuels and Sustainable Development
}

\section{Citation}

Lee, Henry, William C. Clark, and Charan Devereaux. "Biofuels and Sustainable Development." CID Working Paper Series 2008.174, Harvard University, Cambridge, MA, July 2008.

\section{Published Version}

doi:10.2139/ssrn.1282111;https://www.hks.harvard.edu/centers/cid/publications

\section{Permanent link}

http://nrs.harvard.edu/urn-3:HUL.InstRepos:32062577

\section{Terms of Use}

This article was downloaded from Harvard University's DASH repository, and is made available under the terms and conditions applicable to Other Posted Material, as set forth at http:// nrs.harvard.edu/urn-3:HUL.InstRepos:dash.current.terms-of-use\#LAA

\section{Share Your Story}

The Harvard community has made this article openly available.

Please share how this access benefits you. Submit a story.

\section{Accessibility}




\author{
Faculty Research Working Papers Series
}

\title{
Biofuels and Sustainable Development
}

Henry Lee

John F. Kennedy School of Government - Harvard University

William C. Clark

John F. Kennedy School of Government - Harvard University

Charan Devereaux

John F. Kennedy School of Government - Harvard University

October 2008

RWP08-049

The views expressed in the HKS Faculty Research Working Paper Series are those of the author(s) and do not necessarily reflect those of the John F. Kennedy School of Government or of Harvard University. Faculty Research Working Papers have not undergone formal review and approval. Such papers are included in this series to elicit feedback and to encourage debate on important public policy challenges. Copyright belongs to the author(s). Papers may be downloaded for personal use only. 


\section{Biofuels and Sustainable Development}

Henry Lee, William C. Clark and Charan Devereaux

CID Working Paper No. 174

July 2008

(c) Copyright 2008 Henry Lee, William C. Clark and Charan Devereaux, and the President and Fellows of Harvard College

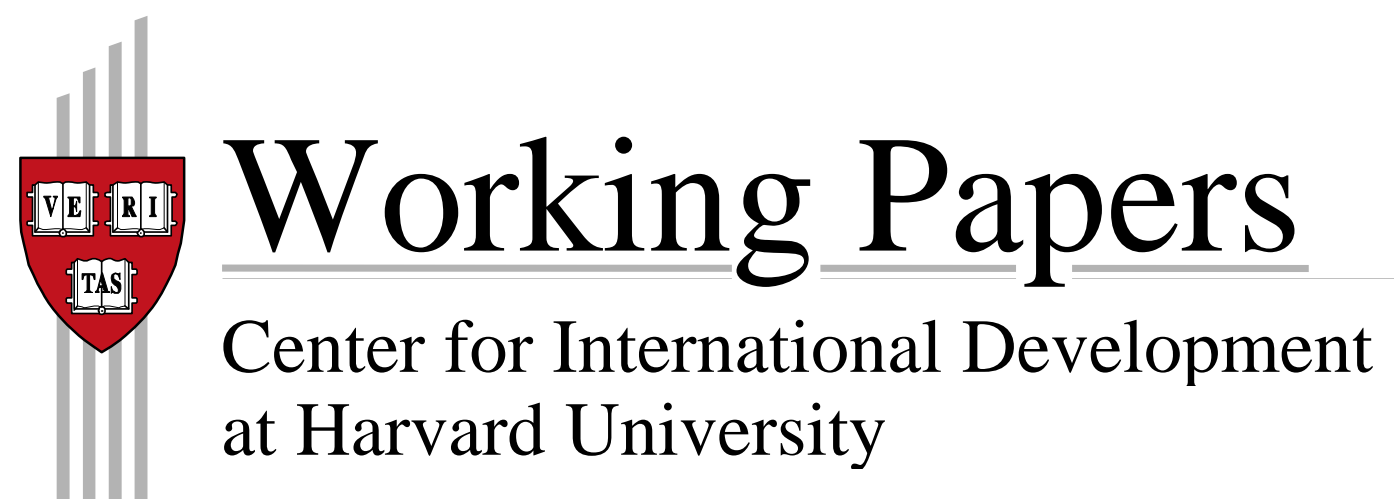




\section{Biofuels and Sustainable Development}

An Executive Session on Grand Challenges of the Sustainability Transition

San Servolo Island, Venice - May 19-20, 2008

Sustainability Science Program, Harvard Kennedy School of Government

Italian Ministry of Environment, Land \& Sea

Venice International University

Authors:

Henry Lee, William C. Clark, and Charan Devereaux

CID Working Paper No. 174

and

BCSIA Working Paper

July 2008 


\author{
Biofuels and Sustainable Development \\ An Executive Session on Grand Challenges of the Sustainability Transition \\ San Servolo Island, Venice - May 19-20, 2008 \\ Sustainability Science Program, Harvard Kennedy School of Government \\ Italian Ministry of Environment, Land \& Sea \\ Venice International University \\ Henry Lee, William C. Clark, and Charan Devereaux
}

\begin{abstract}
The goals and concerns surrounding the debate over government policies related to the greater use and production of biofuels were addressed in an executive session convened by the John F. Kennedy School of Government at Harvard University and the Venice International University on May $19^{\text {th }}$ and $20^{\text {th }}$, 2008. The session attracted more than 25 of the world's leading experts from the fields of policy, science, and business to San Servolo Island for an intensive two day session (see Appendix A for a list of the participants). The discussions were off-the-record, with each participant present in his or her own capacity, rather than representing an organization. The session was one in a series on Grand Challenges of the Sustainability Transition organized by the Sustainability Science Program at Harvard University with the generous support of the Italian Ministry for Environment, Land and Sea. This particular session was held as part of the Ministry’s ongoing work with the Global Bioenergy Program established at the G8 Gleneagles Summit in 2005.
\end{abstract}

This summary report of the session is our synthesis of the main points and arguments that emerged from the discussions. It does not represent a consensus document, since no effort was made at the Session to arrive at a single consensus view. Rather, we report here on what we heard to be the major themes discussed at the session. Any errors or misrepresentations remain solely our responsibility.

Keywords: biofuels, sustainable development, environmental policy, sustainability

JEL subject codes: Q01, Q56, Q4

This paper may be cited as:

Lee, Henry, William C. Clark and Charan Devereaux. "Biofuels and Sustainable Development: Report of an Executive Session on the Grand Challenges of a Sustainability Transition” San Servolo Island, Venice, Italy: May 19-20, 2008. CID Working Paper No. 174. Joint Center for International Development and Belfer Center for Science and International Affairs Working Paper, Cambridge, MA: Harvard University, July 2008.

It is available at http://www.cid.harvard.edu/cidwp/174.htm. Comments are welcome and may be directed to the authors: henry_lee@harvard.edu and william_clark@harvard.edu. 


\section{Grand Challenges of the Sustainability Transition:}

This report emerges from the second in a series of intense workshops and study sessions on Grand Challenges of the Sustainability Transition, organized by the Sustainability Science Program at Harvard University, hosted by Venice International University, and supported by the Italian Ministry of Environment, Land and Sea.

The first session in the series addressed Grand Challenges in Sustainability Science. It was convened in October 2006 by William Clark, Co-Director, Sustainability Science Program at Harvard University; John Holdren, President, American Association for the Advancement of Science and Professor, Harvard University; and Robert Kates, Co-Chair, Initiative on Science and Technology for Sustainability. Further information is available at the workshop web site: www.cid.harvard.edu/sustsci/workshops/06sanservolo/index.html.

\section{The Sustainability Science Program at Harvard University:}

The Sustainability Science Program at Harvard's Center for International Development seeks to advance basic understanding of the dynamics of human-environment systems; to facilitate the design, implementation, and evaluation of practical interventions that promote sustainability in particular places and contexts; and to improve linkages between relevant research and innovation communities on the one hand, and relevant policy and management communities on the other.

Further information is available though the Program web site at www.cid.harvard.edu/sustsci/, or from co-Directors William C. Clark (william_clark@harvard.edu or Nancy Dickson (nancy_dickson@harvard.edu), at the Center for International Development, Harvard Kennedy School, 79 JFK Street, Cambridge, MA 02138 USA.

\section{Environment and Natural Resources Program at Harvard University:}

The Environment and Natural Resources Program at the Belfer Center for Science and International Affairs is the center of the Harvard Kennedy School's research and outreach on public policy that affects global environmental quality and natural resource management. Its mandate is to conduct policy-relevant research at the regional, national, international, and global level, and through its outreach initiatives to make its products available to decision-makers, scholars, and interested citizens.

More information can be found on ENRP's web site at www.belfercenter.org/enrp or from director Henry Lee (henry_lee@harvard.edu) or program administrator Amanda Swanson (amanda_swanson@harvard.edu), at ENRP, Harvard Kennedy School, 79 JFK Street, Cambridge, MA 02138 USA.

\section{Venice International University:}

Venice International University (VIU) is an association made up of ten universities, the Foundation of Venice, the Province of Venice, the Italian Ministry for the Environment and Territory (IMET) and the Italian National Research Council. The aim of this international center 
is to manage higher education and research centers on the island of San Servolo in Venice. VIU's work on sustainability is pursued through The Center for Thematic Environmental Networks (TEN).

Further information is available through the TEN web site at www.univiu.org/research/ten, or from its President, Professor Ignazio Musu (ten@univiu.org), at VIU, Isola di San Servolo 30100 Venice, Italy.

\section{Author Acknowledgements}

A session of this type is made possible by the commitment and hard work of many people. We would like to thank our organizing committee of Corrado Clini, Empedocle Maffia, Melinda Kimble, Ricardo Hausmann, and Robert Lawrence. We are deeply appreciative for the work of Elisa Carlotto and Alessandra Fornetti at Venice International University and to Nancy Dickson and Gloria Visconti for their advice and guidance throughout the process. Charan Devereaux served as the rapporteur and has helped us in the development of this report. Finally we are very grateful to Amanda Swanson, who served as the staff coordinator for the entire project and whose help was essential to the success of this session.

As this report went to press, we received word that our friend and colleague on the organizing committee, Empedocle Maffia, had died in Rome after a short illness. He was instrumental in planning this session, which embodies what Empedocle spent his life doing: bringing together passionately committed individuals separated by their individual perspectives and interests, yet united in a commitment to respectful and reasoned discourse aimed at making the world a little bit wiser and better place. We dedicate this report to his memory, hoping that he would have thought we got some of it right, and missing terribly the wry humor and firm hand he surely would have brought to improving it. 


\section{Table of Contents}

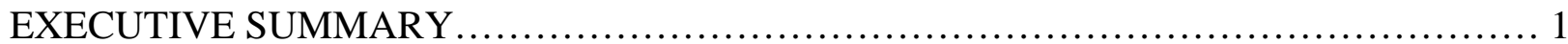

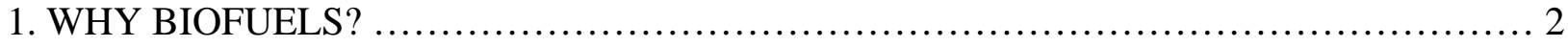

1.1 Energy _ 3

1.2 Climate _ 3

1.3 Economic Development __ 4

2. WHAT ARE THE CONCERNS ABOUT BIOFUELS? ............................................................. 4

2.1 Food versus Fuel __ 5

2.2 Greenhouse Gases __ 5

2.3 Ecosystems _ 6

2.4 Market Concerns __ 6

2.4.1 Trade 6

2.4.2 Incentives _ 6

2.4.3 Infrastructure _ 7

2.4.4 Land Use _ 7

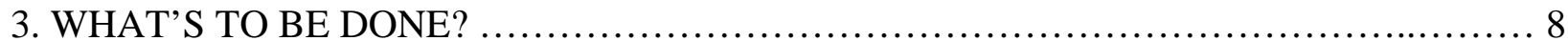

3.1 Industry Development __ 8

3.2 Infrastructure Development __ 8

3.2.1 Public Good Infrastructure __ 9

3.2.2 Private Good Infrastructure __ 9

3.3 Standards and Certification _ 9

3.3.1 Basic Product Standards _ 9

3.3.2 Greenhouse Gas Standards or Certification _ 10

3.3.3 Standards or Certification Relevant to Food and Ecosystem Service Concerns

3.4 Mandates and Incentives 11

3.5 Research and Development 12

3.6 Governance 



\section{Executive Summary}

Liquid biofuels can provide a much needed substitute for fossil fuels used in the transport sector. They can contribute to climate and other environmental goals, energy security, economic development, and offer opportunities for private companies to profit. If not implemented with care, however, biofuel production can put upward pressure on food prices, increase greenhouse gas (GHG) emissions, exacerbate degradation of land, forests, water sources, and ecosystems, and jeopardize the livelihood security of individuals immediately dependent on the natural resource base. Guiding biofuel development to realize its multiple potential benefits while guarding against its multiple risks requires the application of a similarly diverse set of tailored policy interventions. Most session participants agreed that any single rule - such as production subsidies, a simple ban on biofuel production, or the immediate revocation of existing mandates for biofuel use - is too blunt an instrument, and will almost certainly do more harm than good. 


\section{Biofuels and Sustainable Development}

Biofuels have emerged as a centerpiece of the international public policy debate. All of the G8+5 countries, with the exception of Russia, have created transport biofuel targets. Some countries have mandated the use of these fuels. For example, in January of 2008 the European Union reaffirmed a goal that $10 \%$ of vehicle fuel be derived from renewable sources by 2020 . And the U.S. Energy Security and Independence Act requires that 36 billion gallons of renewable fuels be blended into gasoline by 2022. Recently, however, increased food prices triggered in part by converting food crops such as maize to fuel have raised public concerns about such goals. These concerns have been reinforced by several studies which indicate that biofuels may aggravate the net emissions of greenhouse gases rather than reduce them. While the potential benefits of biofuels have induced some governments to embrace their potential, many leaders are now concerned about the costs - particularly those that impact food prices and the environment.

Biomass can be used to provide energy in many forms including electricity, heat, solid, gaseous, and liquid fuels. These bioenergy options have been actively pursued in both the developed and developing world. Further, approximately two billion of the world's poorest people use biomass directly for cooking and heating, often seriously endangering their health and their environment. This Session focused exclusively on one part of the bioenergy menu: liquid biofuels for transportation. The Session asked three principal questions. Why should countries care about biofuels? Why should they be concerned about the negative spillover effects of biofuel production? What can be done to mitigate these negative effects, while promoting the development of a sustainable biofuel industry?

\section{WHY BIOFUELS?}

Policymakers, business representatives, academics, and members of civil society are pushing development of biofuels for different reasons. Some see biofuels as a substitute for high priced petroleum, either to ease the burden on consumers, to diversify the sources of energy supplies, or to reduce escalating trade deficits. Some have focused on biofuels as a way to extend available energy in the context of increasing world demand for transportation fuels. Others target biofuels as a substitute for more carbon intensive energy. Still others see biofuels as an economic opportunity. This latter group can be divided into two sectors: those who see biofuels as an economic development opportunity, and companies who see biofuels as a potential market in which to invest. 
1.1. Energy: The world currently uses 86 million barrels of oil per day, ${ }^{1}$ with forecasts that demand for liquid fuels will increase to 118 million barrels by $2030 .{ }^{2}$ Most of the incremental fuel will come from OPEC and specifically from the Middle East. In the last two years the world's supply of oil has had difficulty keeping up with demand, and prices have skyrocketed to $\$ 140$ per barrel and more. This has triggered economic hardship, especially among the poorest importing countries. As more and more funds are required to pay for oil products, importing countries find their current account balances eroding and the costs of producing and transporting goods and services increasing. Today, many forecasters predict that while prices will fluctuate, the era of low-cost oil is over and countries must adjust by seeking alternative energy options and strategies.

More than $60 \%$ of the oil consumed in the OECD countries is used for transportation. While there are many substitutes for oil in the heating and power sectors, this is not the case in the transportation sector. Fossil fuel based alternatives, such as oil shale and coal liquefaction, could potentially provide additional transportation fuels, but their production will have large impacts on greenhouse gas emissions and water resources. In the short term, producing liquid fuels from biomass is one of the only alternatives to petroleum-based transportation fuels. As a result, countries are looking at a menu of biofuel options to reduce their future reliance on petroleum. Since biofuels are likely to be produced in countries outside of OPEC, they may also allow oil-consuming nations to diversify the sources of their transport fuels, and hence provide energy security benefits. While some debate the significance of the energy security advantages, until alternative transportation fuels (such as hydrogen and electricity) can be produced and consumed at a competitive price, biofuels are one of the few shortterm options available to national governments worried about dependence on imported oil.

1.2. Climate: Growing concern over global climate change has motivated growing interest in all manner of renewable energy sources, biofuels among them. With transport contributing around $25 \%$ of global carbon dioxide $\left(\mathrm{CO}_{2}\right)$ emissions and with very few viable alternative fuels available, biofuels have been presented as a potentially significant contributor to strategies for reducing net greenhouse gas emissions from the transportation sector. There is little question that when produced and used appropriately, biofuels can deliver substantially lower net greenhouse gas emissions than fuels derived from fossil sources. This is particularly true when considering the greenhouse gas intensive synthetic fuels produced from coal or oil shale that are one of the principal alternatives for liquid transport fuels. But the net greenhouse gas emissions of biofuels vary significantly depending on the feedstocks and technologies used in their production and consumption. And the overall impact of biofuel development on climate is more complex still, tied up with differences in carbon 
stocks and solar reflectance between the biomass crops and the vegetation they replace. It seems virtually certain that biofuels will (and should) have a role in national and global strategies to address the dangers of climate change. What is the most appropriate nature, scale, and location of that role remains an open question.

1.3. Economic Development: Biofuels and their feedstocks could be an important source of export income for developing nations. History has shown that participating in the global economy through export activity is a crucial part of the economic development process. In some tropical countries, biofuel production can bring with it "stepping stone" effects such as the extension of transportation networks, as well as job creation. In addition to, or in some cases in lieu of, growing biofuels for export, countries can substitute domestically-produced biofuels for imported oil products, reducing the micro and macro impacts of the sharp escalation in oil prices. In addition, biofuels present an opportunity for new entrepreneurial companies and small holders to emerge while simultaneously increasing economic activity in both developed and developing countries.

\section{WHAT ARE THE CONCERNS ABOUT BIOFUELS?}

Just as there are multiple goals that many seek to achieve through appropriate biofuel production and use, there are also multiple concerns. Many have blamed biofuels for higher food prices. Critics have also questioned the carbon mitigation claims surrounding biofuels. Others have pointed out that some kinds of increased biofuel production may dramatically increase nitrogen flows into lakes, streams, and coastal waters. Intensive use of land to produce biofuels - just like intensive use of land to produce food and fiber - can have serious impacts on conservation and ecosystem services, and on the livelihood security of poor land users. There are economic challenges as well. Many of the poorer tropical countries identified as potential targets for future investments currently lack the transportation and agricultural infrastructure to fully realize the potential of biofuels. Furthermore, trade barriers continue to block the development of a global biofuels market. More generally, critics argue that without appropriate public policy, the potential benefits of increased biofuel production may be outweighed by the costs.

It is important to carefully characterize the concerns raised about biofuels in order to tailor effective policy. Any single policy that attempts to address every challenge simultaneously is almost certain to be ineffective and would likely foreclose the opportunity to realize the potential benefits outlined above. In fact, it is well established that good policy generally needs as many different instruments or interventions as it has targets or objectives. ${ }^{3}$ To address the four or five concerns noted above, good biofuel policy should generally expect to need four or five instruments, each tailored to the particular challenge at hand. Of course reality is more complex, and it will also be important to consider the interactions among such instruments, and to pick 
ones that are mutually supportive. The broader point remains, however, that by being specific and clear about goals and constraints on the one hand, and specific interventions to address each of them on the other, an analytical rather than ideological approach to biofuels can become possible. In this way, policymaking can isolate problems about biofuels and start down the path toward mitigating those problems so as to secure in a responsible manner the potential benefits that biofuels can almost certainly offer to society.

2.1. Food versus Fuel: According to the Food and Agriculture Organization of the United Nations (FAO), global food prices have increased dramatically, rising by nearly $40 \%$ in 2007 and continuing to increase at the time of this session. Nearly all agricultural commodities have been affected, including major grains such as maize, wheat and rice. ${ }^{4}$ The causes of the price hikes include adverse weather in key production areas, higher agricultural input prices (especially oil and oil-derived products such as fertilizers), and limited elasticity in agricultural production capability. Demand for food has also grown, especially in Asia and sub-Saharan Africa. While experts differ as to the extent of its role, increased biofuel production has also clearly played a part in higher food prices, shifting land away from food production and triggering increased competition for land use.

Another major underlying factor in the increase in food prices is that agricultural practices have not kept up with changing challenges and demands. Agricultural research and development has been underfunded for several decades, as have investments in rural infrastructure such as modern irrigation technologies and roads. In addition, energy and environmental policies that have pushed biofuel development have had little interaction or coordination with agricultural policies. Thus, biofuels production has not been fully integrated or embedded in strategic agriculture policy.

2.2. Greenhouse Gases: When measured over the entire production chain, the production of some biofuels, such as sugarcane-based ethanol, results in significant reductions in carbon dioxide emissions compared to conventional gasoline. The production of some biofuels can lead to smaller reductions, or even increases, in net carbon emissions. In particular, Session participants identified the clearing of forests to grow energy crops as a major concern as this practice can release large amounts of carbon dioxide to the atmosphere. Other sources of greenhouse gases emissions were also a cause for concern, such as the oxidation of peat that has resulted from the clearing of swamp forests for oil palm plantations in Indonesia. Several participants pointed out that the significance of $\mathrm{N}_{2} \mathrm{O}$ as a greenhouse gas should not be neglected as its impacts can be exacerbated by biofuel production and use.

Biofuel development that results in an increase in greenhouse gas emissions, rather than a reduction, erodes climate goals. Polices are needed to ensure forest protection and to encourage changes in agricultural practices to reduce net greenhouse gas. There is 
presently a lack of consistent methodologies for carbon emissions accounting that would allow society to precisely assess the impact of different agricultural and forestry practices. The absence of an agreed methodology is a major barrier to the development and implementation of a sustainable biofuels industry and associated policies. This barrier is being addressed by several international organizations including the Global Bioenergy Partnership.

2.3. Ecosystems: While greenhouse gas emissions were a major focus of the Session, they were not the only environmental concern voiced about an expanding biofuel industry. Air pollution, water pollution (especially nitrogen run-off), deforestation, loss of biodiversity, and overuse of water for irrigation in countries that are likely to face increased water shortages over the next several decades are all issues that require close attention in the development of agriculture for both increased food and biofuel production. The extent to which mixed-model development, including production from small holders, might balance ecosystem protection with economic development should be examined more closely.

2.4. Market Concerns: A free and open market for biofuels in which products, technologies, and producers can freely compete on relevant terms will encourage product improvement, capacity growth, and cost reductions. But clearly the environmental land use and economic costs will require regulatory intervention to set minimum standards and create a level playing field. Concerns about the market can be grouped into three areas: trade, incentives, and infrastructure.

2.4.1. Trade: Currently, a world market for biofuels does not exist. Import tariffs and non-tariff trade barriers erected by potential biofuel-consuming nations constrain the emergence of a functioning global market and eliminate economic opportunities for a number of developing countries. Such policies also reduce access to lower-priced biofuels in consuming countries. However, direct competition should be avoided where possible between western farmers intent on protecting their domestic markets and food and fuel suppliers from developing regions intent on identifying and accessing new markets.

2.4.2. Incentives: Session participants raised concerns about the inadequate design of existing incentives and mandates for biofuel production. Many were uncomfortable with mandates, arguing that they often target the wrong goals, and therefore serve as an ineffective instrument for achieving the full potential benefit from biofuels. However, as a recent UNCTAD study pointed out, no country has ever established a biofuels market without the use of mandates and subsidies. Prematurely removing existing mandates would have a chilling effect on the nascent biofuel industry, as investors who have committed funds in response to these mandates might walk away, stranding established 
production capacity. Uncertainty about policy and programmatic consistency was identified as a major constraint on future investment.

Several participants argued that if a second generation of biofuels is to emerge, financial rewards should be linked to reductions in greenhouse gas emissions at all stages of the production chain. Simply relying on prohibitions and other negative incentives to achieve these ends would not be sufficient.

Much discussion centered on biofuel certification processes, and on how to design them to ensure that environmental and developmental goals were addressed. The common sentiment was that these processes, if poorly designed, could severely restrain the market without appreciably improving sustainability or reducing greenhouse gas emissions. Several participants suggested that the principles embodied in the Roundtable on Sustainable Biofuels should be generally supported.

2.4.3. Infrastructure: An additional market challenge is that many of the poorer potential biofuel-producing nations lack the transportation, institutional, regulatory, and service infrastructures to support a biofuel industry.

It is unlikely that investments in this infrastructure will precede investments in biofuel production since development banks will not provide financing unless the demand for the product is clearly identifiable. For example, if the World Bank is to finance a road in the Congo to support a burgeoning biofuels industry, it must have assurances that there will be an industry present to use the road or it will not take on the demand risk. However, unless there is a reasonable probability that adequate infrastructure will exist to transport their products, investors will not put up their money. Significant investments in infrastructure are required, but they must be sequenced in a manner that is reasonable both for the investors and the banks.

Many poorer developing countries lack the regulatory, institutional, and legal systems necessary to induce investors to take the financial risks inherent in building a nascent industry. Their governments are struggling to develop and implement such systems and need technical, and in some instances financial, assistance to design appropriate governance frameworks.

2.4.4. Land Use: The biofuel debate is about how countries use their land. As food and fuel prices increase, competition for the world's land, especially for forests - will become more fierce. Many countries, including those in the developed world, lack the institutional capacity to tailor policies and programs that integrate agriculture, energy and environmental policies into a coherent land use policy. Governments will be under increased pressures to play the 
role of facilitator between local communities, businesses, and interest groups. They presently lack a coherent menu of institutions and policies to fill this new responsibility. For many governments, this would be a particularly challenging and unfamiliar task for which technical assistance and external policy advice may be required.

\section{WHAT'S TO BE DONE?}

What are the most important actions that could be taken to overcome the barriers impeding the use of biofuels for sustainable development? Who should be responsible for those actions?

As noted in earlier sections, many at the Session agreed that a necessary though insufficient step to realize the potential of a sustainable biofuel industry in developing countries is the emergence of an international market to couple supply, demand, and the incentives for investment and innovation at the largest possible scale. Ideally, such an international market would encourage the production of biofuels in locations where they can be grown most efficiently and where undesirable impacts are the smallest, and the consumption of biofuels in locations where the need for them is greatest. There was a strong feeling among the participants that the potential benefits of an international market in biofuels could be outweighed by risks of damage to food and environment systems unless adequate protective measures were simultaneously introduced. These protective measures will likely include the explicit recognition that sustainable production of biofuels cannot be expanded indefinitely. There are intrinsic limits on the productive capacity of ecosystems, constraining yields per unit of available area, and the amount of area that can be dedicated to sustainable biofuels production.

3.1. Industry Development: Support for infrastructure and vastly expanded R\&D are essential for the development of any global biofuel industry. If that industry is to be sustainable, governments must also put into place a portfolio of incentives aimed at minimizing the collateral impacts, including environmental damage, increased food prices, and additional greenhouse gas emissions. Responsibility for action in this arena lies largely with national governments and multi-national firms.

3.2. Infrastructure Development: Biofuel production is infrastructure intensive. At the national level, many poorer countries will find it difficult, especially in the early years, to develop the physical and institutional infrastructure needed to exploit their potential for sustainable production of biofuels unless provided with substantial outside support. Without the means to transport and store both the feedstock and the final product, biofuel companies in poorer developing countries will not be able to attract significant investment. 
3.2.1. Public Good Infrastructure: Much of the needed support is of a public good variety that can generally be provided only by international, bilateral, and private aid programs. Such assistance should be directed to traditional development infrastructure projects such as roads to connect production areas with refining facilities and markets. (Such projects, wherever possible, should be “dual use," providing infrastructure needed for biofuel development that can also support agricultural and other development.)

Additional assistance for public good infrastructure is also needed to support the development of biofuel-related public goods such as research (see below) and production processes that help to reduce environmental impacts that would otherwise be externalized (e.g., highly efficient irrigation and fertilization; low-impact harvest). Responsibility for action in this arena lies primarily with development banks; international, bilateral, and private aid programs; and developing country governments.

3.2.2. Private Good Infrastructure: Some of the infrastructure support needed for biofuel development can generate returns to investors and is thus a potential opportunity for loans or direct foreign investment. Examples include investments in production, refinery/processing, and product distribution facilities. Responsibility for action in this arena lies with banks and multinational firms seeking to develop operations in the producing countries.

3.3. Standards and Certification: Session participants expressed broad agreement with the view that creation of appropriate standards and certification protocols is essential for the sustainable development of biofuels. Certification or standards should be treated as means to advancing sustainable development of biofuels, not as an end in themselves. They need to balance the complexity desired to cover all concerns with the simplicity needed to promote practical and timely development and implementation. Actions are needed to stimulate the development of an efficient market for biofuels while simultaneously guiding that development in sustainable directions. There was support at the Session for the idea that while standards or certification protocols may be needed to realize many of the major goals for the sustainable development of biofuels, efforts to control or regulate biofuels through any single global certification process or standard are likely to fail. Instead certification processes should be targeted towards specific, clearly defined problems that are not, or cannot be, addressed by other regulatory or policy mechanism. A “one measure for all problems” approach relies on an overly blunt instrument and is not likely to succeed.

3.3.1. Basic Product Standards: "Plain vanilla” product standards are needed to facilitate the emergence of a biofuel market by helping buyers and sellers to share an understanding of just what they are bargaining about. (For example, 
3.3.2. Greenhouse Gas Standards or Certification: Depending upon the methods used to produce them, biofuels may have net impacts on the global carbon cycle and on emissions of other critical greenhouse gases that are either positive (releasing less carbon dioxide and other greenhouse gases than fossil fuel alternatives), or negative (releasing more carbon dioxide and other greenhouse gases than fossil fuel alternatives). Several Session participants pointed out that in this respect, biofuels are similar to other uses of land resources, such as food production. They argued that it could unduly constrain realization of the potential benefits of biofuel development to impose different certification requirements for specific emissions on land used to produce fuel than on land used to produce food and fiber. The direct and indirect impacts on land resources from increased demand for biofuels are intrinsically no different than the impacts from increased demand for food.

If, however, biofuel development projects claim that they should receive special treatment or financing because of their supposed contribution to solving the climate problem, then they need to be able to document that contribution for buyers, investors, and regulators. Similar needs exist if landuse interventions generally (e.g. forestry, food, and fiber production) are called upon under future climate agreements to account for their net contribution to greenhouse gas emissions. To provide such documentation, it seemed essential to most Session participants that reliable and standardized life-cycleaccounting (LCA) methods be developed to assess the net carbon budgets associated with particular biofuel and other land use projects. More generally, assessment frameworks need to be developed and applied that will allow us to address the impacts of alternative biofuel strategies not only on greenhouse gas emissions, but also on other determinants of climate change (e.g. surface reflectivity). Responsibility for this area of work lies most appropriately in cooperative action involving the international science community ${ }^{5}$ and the countries/firms involved in biofuel production. 


\subsubsection{Standards or Certification Relevant to Food and Ecosystem Service}

Concerns: Should standards or certification similar to those discussed for greenhouse gases be developed to trace the impact of biofuel development on food production or other ecosystem services? For example, some participants argued that biofuels ought to be grown only on soils that do not support forests, are degraded, or are otherwise unable to support food crops. Those who shared this view were primarily motivated by concerns about the impact of biofuel development on greenhouse gas emissions, the loss of biodiversity, and a host of other environmental consequences, and thus focused their attention on designing a carbon certification process. Still others argued for feedstock-based standards, designed to document which biofuels are produced from non-food feedstocks. There were also concerns that any substantial additions of fertilizer use due to biofuel development could further exacerbate existing problems of eutrophication and “dead zones” in coastal seas.

Others made a case for not stifling biofuel development with requirements that would not be made for other land use projects, e.g. those taking land out of food crop production and into use for fiber crops or for lumber used in building homes. The Session did not come to closure on this issue. There was, however, a general consensus that the best way to handle concerns about the impacts of biofuels beyond greenhouse gases was to build comprehensive plans for assuring food security and the conservation of ecosystem services, and to hold biofuel projects accountable to standards comparable to those imposed on other proposals for land use change (see later section on Governance). Such standards should be developed in a transparent, independent, and participatory manner. Work on such standards has begun in a number of forums, including the Roundtable on Sustainable Biofuels.

3.4. Mandates and Incentives: Targets for biofuel use and incentives for biofuel production have had a major impact on the rate and pattern of biofuel development. Few would argue that these impacts have been optimal. Unintended consequences have emerged because mandates and incentives have often targeted the means (i.e. specific technologies or volumes of use) rather than the ultimate goals of biofuel development. For example, volume mandates have almost certainly pushed producers to use crop feedstocks, since crops tend to have the best developed production technologies and are therefore usually the cheapest way to produce volume. The resulting competition between fuel and food has been a major source of tension. Better incentives should target goals, such as focusing biofuel development on non-food biomass, low net carbon life cycles, or approaches that protect ecosystem services. At the enterprise level, second generation biofuel production is often more expensive than fossil fuel production. Hence companies will seek greater financial rewards and subsidies for 
developing these fuels. Any such rewards or subsidies should be clearly linked to greenhouse gas reductions and the attainment of sustainability goals.

The shortcomings of many existing mandates and incentives notwithstanding, there was a belief among many Session participants that precipitous roll-backs or moratoria on existing mandates or incentives should be avoided. As mentioned in section 2.4, such actions may have serious impacts on biofuel investment, undermining confidence, stranding assets, and generally setting back the development of sustainable biofuels. Needed instead is careful analysis of the mandates, with targeted adjustments only where necessary for sustainability. This should include a limit to extensions of existing mandates or incentives that are not carefully targeted on the ultimate goals of biofuel development discussed in section 1 . In addition, governments should begin an orderly, innovation-sustaining transition toward incentives that are targeted on such multidimensional goals such as reduction of net GHG emissions, increasing utilization of non-food feedstocks, the attainment of sustainability targets, the conservation of biodiversity, etc. Responsibility for this action arena lies primarily with national and regional governments in the United States, European Union, and other powerful markets. Important assistance could come, however, from the international community of scholars and policy experts who should help develop "model incentives" for nations to consider when designing incentive packages appropriate for their own particular contexts.

3.5. Research and Development: Advancing a strategy for sustainable development of biofuels that meets concerns for availability, cost effectiveness, greenhouse gas reductions, food competition, and ecosystem protection will be a knowledge-intensive activity. A great deal of R\&D is currently focused on the engineering and molecular biology of biofuel production. Some R\&D resources are directed towards the relevant aspects of the global carbon cycle and some into biofuel production processes. Very little is going into research on the agricultural and natural resource systems needed to sustainably "scale up" a significant biofuel production system, into the limits of sustainable expansion, or into the ways that biofuel production interacts with the environment at global, regional, and local scales. ${ }^{6}$ Indeed, for years, the international system has neglected research and development in the agriculture and natural resource sectors. Even the most basic food and fiber crops have suffered from underinvestment. For the complex, multi-use landscapes ${ }^{7}$ that will almost certainly be an essential component of a strategy for sustainable development of biofuels, only the very beginnings of the necessary knowledge base exist. Along with a lack of investment in biotechnology, irrigation, and roads, this underinvestment in knowledge has resulted in a long-term decline in land productivity. Food, fiber, and fuel production could be stimulated by increasing investment in research and supporting reforms targeted at increased production of multiple crops to serve multiple uses. The interactions among 
agriculture, energy, and the environment require that more of the research should be interdisciplinary in nature and should focus on the boundaries between these three fields. Some Session participants recommended doubling the public agriculture budget to revitalize the system, including support to the relevant research centers of the Consultative Group on International Agricultural Research (CGIAR). Such a reinvigoration of the CGIAR system, and its collaboration with other public and private sector experts in engineering and molecular biology, could begin to grow the necessary research capacity for sustainable development of biofuels. Responsibility for action in this area resides jointly with the international scientific community (which needs to develop a strategic science plan on sustainable biofuels), the national and international funders of the CGIAR, related public goods research institutions, and large privatesector actors active in the biofuels arena.

3.6. Governance: The increased demand for food and the emerging interest in biofuels has created a new challenge for governments at all levels. Biofuels are not only an energy issue, but also have major land use implications and thus must be approached from energy, agriculture, and conservation perspectives; all of which come together in land use. Most national governments separate agricultural, energy and environmental policy and natural resources planning into separate agencies. Too often the decision processes are stove piped with each agency focusing primarily on its own mandate and embracing the needs and demands of its own constituencies. In addition, the coordination between national governments and local and regional governance institutions where most of the land use decisions are made, is poor, or in some cases, non-existent.

Participants felt that it was important that biofuels not be the primary driver of land use policy. National governments should embrace the principles of integrated planning, but to do this they must be able to tap into and coordinate the interests of the many diverse stakeholders. This coordination can best be achieved at the local or regional level, which means that the role of the national governments becomes more that of a facilitator, providing guidance, financial assistance, and technical support to local and regional institutions. Local governments will often not have the technical capacity to design and develop the matrices to measure the impacts of land use changes. Thus national governments should provide technical guidelines and implementation training to sub-national governments. It also means that the relevant national agencies must develop coordinating mechanism, both among each other and with local entities. Responsibility for this action arena should lie primarily with national governments, but guidance and information should be supplied by international institutions including the multilateral development banks. The best way to develop such internationally recognized guidance and information is almost certainly through multi-stakeholder mechanisms such as the Roundtable on Sustainable Biofuels and the Global Bioenergy Partnership. 
${ }^{1}$ BP, Statistical Review of World Energy 2008. Available at http://www.bp.com/productlanding.do?categoryld=6929\&contentld=7044622, visited June 2008.

${ }^{2}$ US Energy Information Administration, International Energy Outlook, 2007. Available at http://www.eia.doe.gov/oiaf/ieo/oil.html, visited June 2008.

${ }^{3}$ These relationships were first articulated by Jan Tinbergen, On the Theory of Economic Policy, Amsterdam: North Holland Publishing, 1952, and subsequently elaborated by many others, e.g. A.J. Hughes Hallett, "Econometrics and the Theory of Economic Policy: The Tinbergen-Theil Contributions 40 Years On," Oxford Economic Papers, vol. 41, 1989, pg. 189-214.

${ }^{4}$ Mark W. Rosegrant, "Biofuels and Grain Prices: Impacts and Policy Responses," Testimony before the U.S. Senate Committee on Homeland Security and Governmental Affairs Committee, May 7, 2008.

${ }^{5}$ For example, the International Agricultural Research Centers, International Council for Science, the International Academies of Science. See also the section on Research and Development.

${ }^{6}$ See, for example, the recent review of biofuels research in the US Federal system published by the National Research Council, Transitioning to Sustainability Through Research and Development on Ecosystem Services and Biofuels: Workshop Summary, Washington DC, 2008. Available at http://www.nap.edu/catalog/12195.html

${ }^{7}$ Landscapes that we know can simultaneously generate incomes and food and fuel and other ecosystem services. 


\section{Appendix A: Participants}

William Clark

Harvard Kennedy School

Corrado Clini

Ministry for the Environment Land \& Sea - Italy

Henry Lee

Harvard Kennedy School

Melinda Kimble

United Nations Foundation

Ricardo Hausmann

Harvard Kennedy School

Robert Lawrence

Harvard Kennedy School

Empedocle Maffia

World Bank

Gloria Visconti

Ministry for the Environment Land \& Sea - Italy

Jean-Philippe Denruyter

WWF

Rocio Diaz-Chavez

Imperial College London

Janine Ferretti

Inter-American Development Bank

Chris Field

Stanford University

Louise O. Fresco

University of Amsterdam

Lin Gan

CICERO

Guido Ghisolfi

Gruppo Mossi \& Ghisolfi

Tatsuya Hirano

Ministry of Foreign Affairs - Japan

Robert Howarth
Cornell University

Ibrahim Assane Mayaki

Rural Hub

Nadine McCormick

International Union for Conservation of Nature

Darran Messem

Shell International Petroleum Co Ltd

José Roberto Moreira

Centro Nacional de Referência de Biomassa

Ignazio Musu

Ca'Foscari University of Venice

Philip New

BP

David Noe

Ministry of Finance - Chile

Michael Obersteiner

Intl. Institute for Applied Systems Analysis

Mark Radka

United Nations Environment Programme

Mark Rosegrant

International Food Policy Research Institute

Alan Roth

Fitzroy Partners

Robert Sandoli

U.S. Department of State

Daniel Schrag

Harvard University

Meine van Noordwijk

World Agroforestry Centre 